\title{
U.S. URBAN POLICY: THE POSTWAR STATE AND CAPITALIST REGULATION
}

\author{
RICHARD FLORIDA $^{\dagger}$ and ANDREW JONAS ${ }^{\ddagger}$
}

\section{Introduction}

What is the precise legacy of federal urban policy? How does it fit into the broader political economy? What causes it to change in terms of its form, content and socio-spatial effects? These are some of the questions addressed in this paper. In the following, we provide a theoreticized history of federal urban policy and focus on its political-economic determinants. Our argument follows recent work which situates State interventionism in relation to different regimes of capital accumulation (Aglietta, 1979; Hirsch, 1983; DeVroey, 1984). This "regulationist approach" links transformations in the economic sphere to transformations in the political and social spheres.

The main thesis can be summarized as follows. The particular form of mass-production Fordism that arose in the U.S. and the specific struggles that it in part set in motion in the 1930s and 1940s placed severe limits on State intervention in the postwar period. The very restricted State policy response in the postwar period included a set of urban policy measures which, while invigorating the mass productionmass consumption circuit of the U.S. political economy, did not and could not address the root causes of urban and structural-economic problems that emerged later in the postwar period. As such, U.S. urban policy was to a large extent a "failure" from the start.

In developing our thesis, we invoke a "broad" definition of urban policy to include federal expenditures and substantive programs which have had both explicit and implicit effects on patterns of social development within cities. Many so-called "non-urban" (or implicitly urban) policies such as highway spending programs and federal regulation of financial institutions have affected and continue to influence the growth and development of urban areas as much as explicit urban policies such as federally-financed and locally-administered income-assistance programs (Peterson, 1985: 24-29).

† Center for Economic Development, School of Urban and Public Affairs, Carnegie Mellon University, Pittsburgh PA 15206.

キDepartment of Earth Sciences, University of California, Riverside CA 92521. 
The social effects of explicit federal urban policy measures have recently become matters of considerable debate. Conservative critics like Charles Murray (1984) have argued in favor of reducing federal outlays on income-maintenance and housing programs to cities because such programs reproduce poverty due to their work-disincentive effects. Juxtaposed to the conservative viewpoint is the argument that the present rescinding of federal commitments to the cities represents a "new class war" sponsored by capital, implemented by the federal government, and directed at poor people (Piven and Cloward, 1982). What is perhaps most striking about these debates are the simplistic and ahistorical views that they present of the role of the federal government in shaping the fortunes of cities and class, race, gender, and ethnic interests within them. While there is substantial empirical merit to the debates, such arguments are insufficient because they do not provide a theory of the underlying determinants of urban policy.

Our argument integrates three basic themes. First, we argue that federal urban policy originated as an historically and geographically specific response to a structural accumulation crisis in the Great Depression. This crisis was manifest as a "dis-synchronization" of mass production and mass consumption. Given this context, the form and content of State response to this crisis was informed by social struggles and class conflicts in the major cities where capital and people were already concentrated. These social struggles precipitated a wave of institution-building and policy experimentation on the part of the federal government out of which the New Deal urban programs emerged. Such institutions and policy responses were directed in large measure to "reconcile" the disjuncture between production and consumption.

Second, while early policy experiments were rather loosely bounded, later State intervention in urban policy evolved within the bounds set by what we refer to as the "closure of the New Deal". By this we mean the turn away from more "social-democratic" urban policies (eg: full employment and progressive income supports) towards policies which had more restrictive effects on stimulating working class consumption and regulating demand (eg: federally-supported suburbanization). The closure of the New Deal, and the emergence of a "suburban-defense" economy (Florida and Feldman, 1988; Walker, 1981), fixed the trajectory of postwar urban policy creating strict limits on further State intervention. Even the Great Society emerged within this very narrow and restricted set of policy options. Given this context, the urban policy programs of the 1960 s were unable to address ongoing structural problems and were limited to providing incremental and temporary improvements in the conditions of economically marginalized social and racial groupings in the major cities.

Third, beneath recent developments we find a general unravelling of political economic relationships and the demise of the relatively stable 
institutional arrangements upon which postwar economic growth was premised. The dismantling of federal expenditures and substantive programs in the cities, particularly in the areas of income-maintenance and housing, is thus reflected in and reinforced by the general decline of the postwar political economy. In this regard, the present period is important not simply because it signals the end of the more "socialdemocratic" policy experiments begun in the New Deal but because it creates the potential for renewed policy experimentation and institution building at all levels within the State apparatus. The form and content of federal urban policy which may arise from this present period will therefore be conditioned by ongoing social struggles and class conflicts, and the territorial bases of those struggles and conflicts.

\section{Regulation Theory, State Policy, and the Territorial Expression of Social Conflict}

In this section, we lay out a basic theoretical framework from which to view U.S. urban policy and within which to situate our argument. The basic perspective we employ is that of the continental "regulation school" of political economy. In our particular application of regulation theory, we are mainly concerned with the dynamics of relations among the economy (defined as a specific regime of capital accumulation), the social relations of class, race, ethnicity and gender, the territorial expression of those social relations, and the State (defined here as relations between federal and local branches within the apparatus of U.S. government).

Two main concepts form the basis of regulation theory: "regime of accumulation" and "mode of regulation" (Aglietta, 1979; DeVroey, 1984; Lipietz, 1986; 1987). The "regime of accumulation" refers to the underlying economic bases of society and essentially implies a balance between production and consumption which achieves an efficient allocation of social product among profit, reinvestment and consumption. The "mode of regulation" is the institutional structure of the political economy, including economic institutions, the State, the built environment, and spatial patterns, which give coherence to the regime of accumulation. These elements are not automatically generated, so "modes of regulation" are distinctly historical entities created as outcomes of political struggles (Lipietz, 1987).

The Fordist mode of regulation entails a balance between mass production and mass consumption in the postwar era. In its U.S. variant (Jessop, 1988), Fordism entailed amongst other things the rise of assembly-line mass production, a finely grained division of labor in the workplace, high degrees of functional specialization, multidivisional corporate organization, and the application of Taylorist techniques of 
scientific management to the production and labor process (DeVroey, 1984; Davis, 1986; Noel, 1987). Transformations in the spheres of civil society and the State are also regarded as central to the U.S. variant of Fordism, particularly the emergence of the industrial unions, mass education, the expansion of credit, social Keynesianism, and privatized mass consumption of consumer durables (Aglietta, 1979). By linking productivity increases to increases in wages and demand via a variety of institutional arrangements, Fordism was associated with a relatively stable period of economic growth in the postwar U.S. political economy. Since the mid-1960s and early 1970s, however, we have witnessed the unravelling of the institutional arrangements underpinning the Fordist model of economic growth and, according to a variety of authors, their replacement with yet-to-be realised new institutional arrangements, sometimes described as post-Fordist (Storper and Scott, 1989).

Despite their insights, regulation theorists have underestimated the role of the State in shaping particular regimes of accumulation and have implied a functionalist relationship between economic requirements and State interventionism (Bonefield, 1987; Clarke, 1988; Hirsch, 1983; Holloway, 1988; Jessop, 1988). There is, however, nothing necessary in the nature of capital accumulation which requires a particular form of State intervention; State intervention and policy are contingent upon class struggle and social conflict. Once a particular regime becomes institutionalized, State forms and functions may become necessary to the reproduction of that regime, and these can create a degree of long-term "structured coherence" within the overall political economy (Clarke, 1983; Harvey, 1985). In addition, particular regimes of capital accumulation are in fact produced out of struggle and conflict, and central to this process of institution-building are mutually reinforcing patterns of adjustment between the economy, society, and the State.

Geography and territorial development are central to this model of the relations between the economy, society, and the State. As numerous scholars have argued, territory is a fundamental dimension of social life in both the private and public spheres (Scott and Storper, 1986; Wolch and Dear, 1989). We see territory as central to our analysis at three levels.

First, regimes of capital accumulation are always constituted geographically, and are shaped by historical and geographic circumstance. For example, the variant of Fordism that emerged in the U.S. in the postwar period was ultimately shaped by contextual circumstances peculiar to the U.S. political economy, including the unique position the U.S. held in the developing world-economy of capitalism in the postwar period (Agnew, 1987; Florida and Feldman, 1988). This is important because, as shall be argued, the closure of the New Deal and the tran- 
sition to the suburban economy of the postwar period in many ways reflected this unique position and the federal response to it.

Second, the nature of State intervention has been, and continues to be, shaped by the fact that the principal form of territorial development in the U.S. has been urbanization on a large scale (Harvey, 1985). The concentration of people, capital, and new technologies into large urban centers and metropolitan areas has in many ways demanded urbanorientated responses to accumulation crises and social conflicts. These responses have been further conditioned by the internal territorial fragmentation of the U.S. political system.

Third, the spatial responses to economic crises and social conflicts in one period of social development condition the spatial responses in subsequent periods. For Massey (1984), there are geographical "rounds of investment" which include forms of State intervention such that investments and policies in one period create conditions in the landscape (for example, new class relations and forms of local politics) which affect subsequent "rounds of investment". Thus the closure of the New Deal accelerated decentralization tendencies in the political economy which quite literally opened up a space for both urban renewal and the urban policy experiments which emerged in the Great Society period. But it was urban-based social struggles borne out of reconstituted class and political relations in cities which precipitated the actual form of the response of the federal government.

\section{Setting Up the System: U.S. Urban Policy in the Great Depression}

The origins of direct State intervention in U.S. cities can be traced to the onset of the Great Depression. The seeds of an accumulation crisis were sown in the first decades of the century and especially in the expansionary period of the 1920s. During that period, the introduction of Taylorist techniques of scientific management in combination with the semiautomatic assembly line led to tremendous productivity increases in several sectors of the economy. This opened up the potential for increases in workers' wages to match those increases in productivity without at the same time seriously impinging upon corporate profits. As a measure of this growth potential, national income rose from $\$ 60$ billion in 1922 to $\$ 87$ billion in 1929 (Chandler, 1977).

Steady increases in output were not matched by a concomitant increase in demand, however. This was despite the intensification of labor unrest in the period 1900 through to the First World War which put upward pressure on wages (Green, 1980). The majority of industrialists responded to strikes, and more generally the class struggle, by cutting 
wages and hastening the adoption of new labor process technologies associated with assembly-line mass production. A very few, such as Henry Ford, raised wages and standardized work hours as a means to extract value and simultaneously increase levels of working-class consumption. Wage cuts further exacerbated income differentials and undercut the consumption dynamic necessary to sustain economic growth. Even the debt explosion of the 1920s in home mortgages, consumer credit and municipal bonds could not prevent the impending structural crisis of accumulation.

The accumulation crisis which set in motion the Great Depression provided the context within which extensive State intervention in the overall economy, and a nascent urban policy, became both possible and necessary. To a great extent, State intervention was concerned with stimulating or "organizing" demand, quelling social unrest in the factories and the cities, and creating an environment for coordinating production and consumption. Increased State intervention in the economy was not necessitated by the sweeping transformation of industrial production in the decades prior to the depression; rather it was a contingent outcome of social and political conflict, and actual policy evolved as a series of experiments. In particular, it was the intense class and social struggles which occurred in the cities, and the fiscal crises of municipal local governments, which gave shape and form to the urban policy experiments associated with the New Deal.

Housing was a major area of federal urban policy activity. A number of factors were important here: the collapse of the banking and mortgage finance systems, serious unemployment in housing related industries, social struggles in the cities which precipitated demands for jobs and new economic development initiatives, and rising popular demands for federal housing assistance. Created in response to these competing pressures, federal housing policy developed along two basic axes: one involved institutional innovations in domestic banking and mortgage finance; the other revolved around the provision of low-income, public housing.

The former axis focused on the private mortgage finance system. The Federal Home Loan Bank (FHLB) Act of 1932 set up a system of regional home loan banks analogous to the Federal Reserve both to regulate and provide credit to mortgage-lending institutions. Alongside it, the Federal Savings and Loan Insurance Corporation (FSLIC) provided depository insurance for housing finance institutions (Stone, 1973; Starr, 1975; Semer, 1976). The establishment of federal mortgage insurance under the Federal Housing Administration (FHA) allowed mortgage lenders to experiment with low interest, low down payment, longterm, amortized mortgages. Taken together, these policy innovations insulated mortgage lending from other components of the financial markets and created a 
self-contained system for mobilizing housing credit (Florida, 1986a; 1986b).

The New Deal also witnessed significant, if temporary, experiments in socialized mortgage finance. The Home Owner's Loan Corporation (HOLC) made federal funds available to refinance private mortgages that were in danger of default or foreclosure. It thus functioned as a centralized public mortgage lending institution operating parallel to the existing system of thrifts. Until it was disbanded, HOLC refinanced some 1 million mortgages, one out of every five mortgaged properties. Based upon the HOLC experience, the Roosevelt administration later made an abortive attempt to establish publicly-capitalized, or nationalized, mortgage lending institutions, referred to as National Housing Associations, to stimulate housing construction and economic development (Fish, 1979).

Public housing had somewhat different origins. Urban struggles over the availability of affordable housing translated into a national struggle which, broadly-speaking, pit a diverse coalition of progressives, organized labor, unemployed workers, tenants' groups, and housing reformers against housing industry interests such as the National Association of Real Estate Boards (NAREB), construction companies, the United States Savings and Loan League (USSLL), and the National Association of Home Builders (NAHB), as well as conservative business elements like the U.S. Chamber of Commerce and the National Association of Manufacturers (NAM) (Parson, 1984). Organized labor supported public housing because it helped to create "jobs not housing" (Jackson, 1985: 221).

Continued stagnation in housing markets, worsening economic dislocation, and intense housing-related social unrest in the cities broke this stalemate. The Public Works Administration (PWA), established under Title II of the National Industrial Recovery Act of 1933 (Ferguson, 1984; Hawley, 1966; Himmelberg, 1976; Kolko, 1976), pioneered federal intervention in public housing. Between 1933 and 1937, approximately 22,000 public units were completed under its auspices (Fish, 1979). Pressure from housing activists in the context of worsening economic dislocation ultimately forced Congress to pass the Wagner and Steagall Public Housing Act in 1937. This bill established the United States Housing Authority (USHA) to grant long-term, low interest loans from the federal government to local housing authorities for the development of public housing. Under it, the federal government covered up to $90 \%$ of the costs of land clearance and low-income housing development in central cities. As a compromise with conservative housing industry interests, the Act contained an "equivalent elimination" provision which limited public housing construction to the replacement of existing units and did not allow the expansion of the low-income housing stock 
(Bratt, 1986). By 1938, 35 States had passed enabling legislation, and by 1941 there were 622 local public housing agencies in place in different cities. The total number of homes constructed under the public housing program increased from less than 5,000 units in 1935 to 87,000 units some $10 \%$ of all new home construction - in 1941.

New Deal housing policy was carved out in response to evolving economic conditions and social struggles which precipitated conflicts at all levels in the political system, especially the local and federal levels. There was little consensus on how to organize housing delivery and substantial experimentation with a variety of different approaches. As a consequence of this experimentation, by the late 1930s, three parallel and alternative models for housing provision were supported by the federal government: private housing finance insured by the federal government; nationalized housing finance; and public housing. In retrospect, it is ironic to note that the first of these three operated the least successfully during the depression.

A second area of State intervention entailed the use of federal expenditures to provide relief, bolster personal incomes, and quell social unrest in the cities. Economic dislocation and falling personal incomes gave rise to a burgeoning urban-based social movement for federal relief assistance, especially since many municipal governments no longer had the fiscal resources to support their own relief efforts. This movement was organized under the broad umbrella of the Workers' Alliance of America which included unions, religious groups, the Socialist Workers' Committee on Unemployment, the Communist Party's Unemployed Councils and A.J. Mustie's Unemployed Leagues. These groups spearheaded local, urban-based actions such as sit-ins at municipal relief offices, as well as national mobilizations and marches (Piven and Cloward, 1977: 41-95).

The Great Depression focused considerable attention on the existing welfare delivery system. Prior to the New Deal, relief was purely a municipal function or was administered through private charitable donations and the efforts of church and other local organizations (Orloff and Skocpol, 1984). Mounting political and economic pressure on municipal governments, and the accompanying social unrest in cities, resulted in a series of bills which transferred financial responsibility for welfare relief to the federal government. The Emergency Relief and Construction Act of the Hoover years made $\$ 30$ million in federal funds available for relief. The Federal Emergency Relief Act of 1933 appropriated an additional $\$ 500$ million for State and local relief agencies (Romascu, 1983: 64-65; U.S. Advisory Commission on Intergovernmental Relations, 1980). More significantly, the Social Security Act of 1935 redefined the nature of State intervention in the provision of relief and signalled a massive change in intergovernmental relations. This act 
created the formal structure for a nascent "welfare state" in the U.S., ushering in federal support for income maintenance programs administered locally (Aid to Dependent Children), unemployment insurance, disability payments, and old age assistance (Berkowitz and McQuaid, 1980). As a result of these programs, federal welfare expenditures increased from roughly $\$ 1$ billion in 1932 to more than $\$ 6$ billion in 1936 , while total relief assistance rose from $\$ 4.3$ billion to more than $\$ 10$ billion over the same period (U.S. Bureau of Census, Historical Statistics, 1975).

A third level of State intervention involved federal spending on public works and infrastructure. These programs were part of a broader package of measures designed to stimulate economic growth through the use of fiscal and monetary policy, and they served more as protoKeynesian tools to manage economic recovery than as a coherent urban policy per se. They were a response to more general patterns of economic dislocation and unemployment, and the serious fiscal crises facing local governments.

The Great Depression had a devastating impact on municipal finance. Many municipal governments had overextended themselves during the expansionary period of the $1920 \mathrm{~s}$. The collapse of the municipal bond market in 1931 eliminated debt as a source of funds and led urban mayors to organize for intergovernmental fiscal assistance (Gelfand, 1975: 32-34). Some 1,0000 cities actually defaulted on their obligations during the 1930s, resulting in local capitalist interests imposing austerity measures on municipal governments (Horan, 1986; Shefter, 1987). The proposed Wagner-Garner bill of 1932 sought to use the Reconstruction Finance Corporation to provide federal assistance to state and local governments. Established under the Hoover Administration, the Reconstruction Finance Corporation was transformed into a comprehensive "National Development Bank" under the Roosevelt Administration (Romescu, 1983). There were also abortive attempts to establish a National Municipal Bank to help finance local governments. Although the Reconstruction Finance Corporation did provide bailouts to private corporations and banks, only a handful of cities received federal debt assistance.

Instead, State intervention to cope with municipal fiscal stress took the indirect form of federally-financed and administered public works programs to create jobs and stimulate local economic development (Gelfand, 1975; Teaford, 1986). The Civil Works Administration made some $\$ 700$ million available for public works projects in 1933 and 1934 (Barocci, 1979; Leuchtenberg, 1963: 120-125); and the Public Works Administration made an additional $\$ 4.8$ billion available for infrastructure projects. In 1935, the Works Progress Administration was set up as a vehicle for job creation and economic development through 
infrastructure improvement. It provided more than $\$ 11$ billion in direct federal funds for the cities, was associated with a variety of institutional innovations in municipal government including the creation of administratively separate transportation authorities, and eventually generated some 8.5 million jobs over the course of the depression.

Related to this was the rise of federal programs devoted to financing urban transportation systems. The Emergency Relief and Construction Act (1932) and the Hayden-Cartwright Act (1936) provided federal appropriations for urban transportation for the first time in U.S. history. There were similar provisions in the areas of municipal water supply and sewer system construction. Between 1932 and 1940, some $\$ 2$ billion was committed to expressway and street construction, setting a precedent for greater federal intervention in urban infrastructure in the postwar era.

Taken together, these urban programs and expenditures forged a unique bond between the federal government - in particular the national Democratic Party - and big-city political forces. As numerous commentators have pointed out (Gelfand, 1975; Mollenkopf, 1983), federal urban policies initiated in the depression underwrote municipal spending, put people to work, and enabled local governments to broker political conflict more effectively. ${ }^{1}$

To summarize, the New Deal did not see the emergence of a coherent and integrated urban policy but a series of ad hoc and at times contradictory programs and expenditures which arose in response to particular political-economic conditions. Despite this, the combined trajectory of New Deal policies was clearly towards some form of urban-directed Keynesian "social democracy". As a measure of this, Table 1 summarizes the outlays of the federal government on economic development, relief, and public works between 1934 and 1939.

The form and content of urban policy in the Great Depression was thus part and parcel of the more general role played by the State in addressing the consequences of the structural economic crisis. This eventually led to the emergence of a strong commitment to demand management and a form of national economic planning which moved the U.S. closer than any other industrialized nation-state at that time to "social democracy", with the possible exception of Sweden (Collins, 1981; Gourevitch, 1986: 124-180).

\section{The Closure of the New Deal and the Redirection of Urban Policy}

The immediate postwar period saw the closure of the New Deal and a significant redirection in the form and content of urban policy. This closure can best be described as a shift from "social-democratic" policies designed to achieve full employment, to house people, and to bolster 


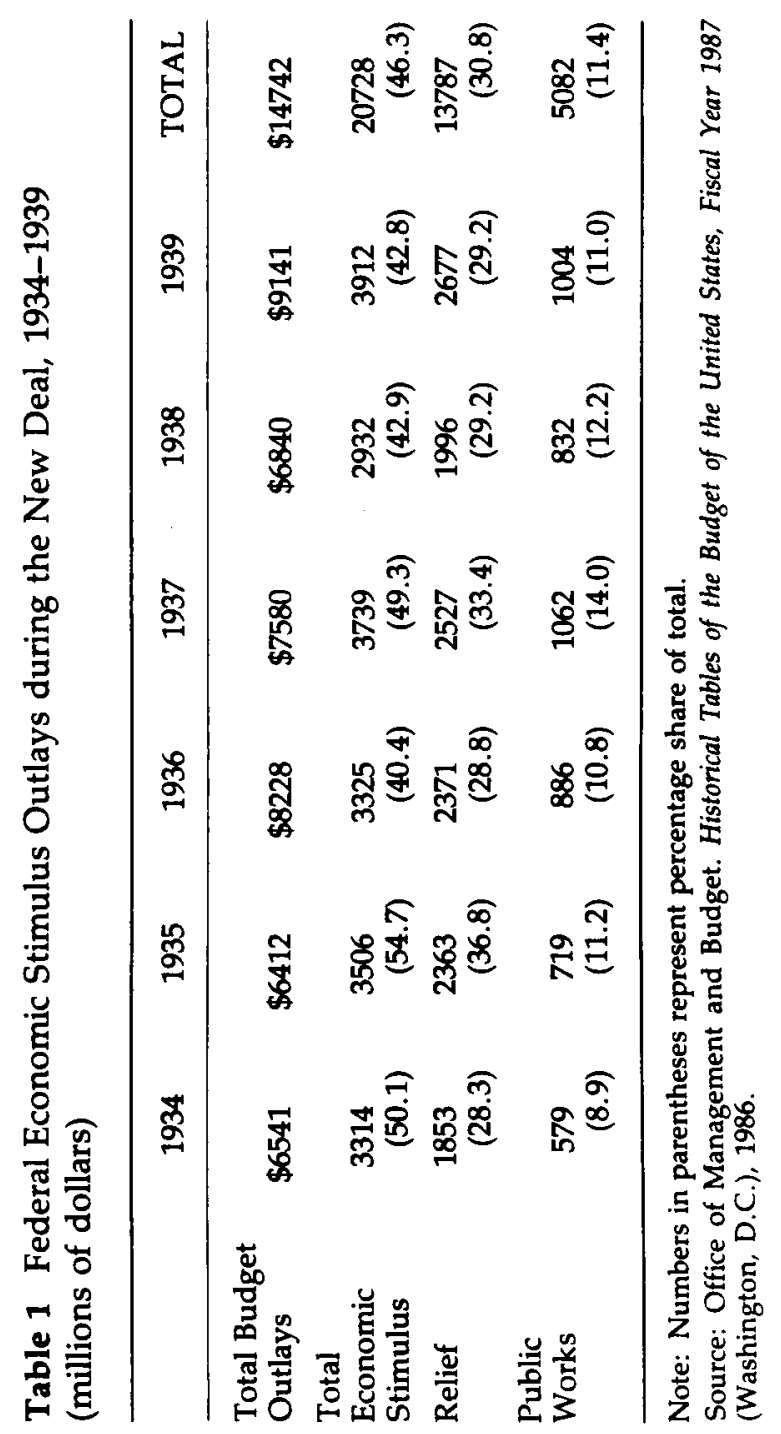


the social wage to federal policies and expenditures which had more restricted effects on stimulating working class consumption, mass education, homeownership, and central-city economic revitalization. In this context, suburbanization and central-city urban renewal were critical developments, being two sides of the same overall urban policy dynamic of this period (Walker, 1981). This new urban policy dynamic became possible in the context of, and indeed was itself constitutive of, the consolidation of a Fordist regime of accumulation in the postwar U.S. political economy. Four developments were of primary importance here: an intensification of class struggle during and immediately after the Second World War leading to the imposition of a limited "class accord" between capital and labor; the increased working class consumption that this "accord" made possible; the unique and privileged position of the U.S. in the postwar world-economy of capitalism; and state expenditures and policies associated with the emergence of the postwar military-industrial complex.

The closure of the New Deal was by no means natural or automatic, but was produced by changing economic conditions and political struggles. Indeed, the decade spanning the late 1930s through to the late 1940 s saw the U.S. move closer in the direction of "social democracy" before turning permanently away from it. Capitalist interests not only had supported full employment during this period but had also worked on "social Keynesian" policies in the Depression (Collins, 1978; 1981). For example, the Business Advisory Council produced a publication in 1938 entitled Towards Full Employment. Towards the end of the war, the fear of a postwar depression and escalating industrial conflict motivated capitalists and progressives in government to think in terms of a significant role for the State in the postwar economy. This was perhaps best reflected in Roosevelt's "economic bill of rights" and the abortive Full Employment Act of 1946 which together were designed to use federal fiscal and monetary policies to achieve full employment (Collins, 1978; 1981). The basic idea was to integrate various components of New Deal urban policy including housing and public works into a comprehensive national economic plan. As late as 1948, Truman ran on a "Fair Deal" ticket which promised full employment, a revived public housing program, and a commitment to income maintenance and civil rights legislation (Markowitz, 1973: 267-297; Wolfe, 1981).

This trend towards "social democracy" was reversed in the late 1940s as the U.S. emerged as a leading force in the postwar world political economy and multinational industrialists and bankers on the Business Advisory Council and the Committee for Economic Development shifted their positions (Ferguson, 1984). Right at the end of the war, the Committee for Economic Development released a landmark study Monetary and Fiscal Policy for Greater Economic Stability which outlined a much more 
circumscribed role for the State than the earlier Business Advisory Council study. In this context, and with the development of the Cold War in international relations, the powers of the State were increasingly brought to bear on the labor movement, eventually leading to the purging of Communists and Socialists from the trade unions, the "Red Scare" and McCarthyism, the expulsion of progressives from the Congress of Industrial Organizations (CIO) and its merger with the American Federation of Labor (AFL), and the passage of the 1947 TaftHartley Act and the 1950 McCarran Act which respectively prohibited secondary boycotts (as well as other forms of expression of workingclass solidarity) and purged left elements from the trade union movement (Bernstein, 1970; Brody, 1980: 82-172; Bowles and Gintis, 1982: 65-66).

Out of this intense class conflict, there emerged a unique, but very restricted, "class accord" between capital and labor (Bowles and Gintis, 1982; Bowles, 1982; Edwards and Podgursky, 1986). This accord established restrictive conditions within which unionized workers could organize and engage in collective bargaining and it ensured them relatively stable long-term employment, standardized pay scales, and a shorter working day. In exchange, unions accepted capitalists' prerogatives over enterprise decision-making and channelled their efforts into improving the standard of living for their members.

Above all else, the "accord" created a stable Fordist regulative environment in which the productivity increases in assembly-line mass production could be matched by a concomitant increase in the wages of workers, and consolidated an intensive regime of capital accumulation within the broader rubric of the U.S. political economy (Aglietta, 1979; DeVroey, 1984; Davis, 1986; Noel, 1987). The "accord" thus established the political-economic conditions for the shift from full employment "social democracy" to limited State intervention via demand-management, and the closure of the New Deal.

The unique and privileged position of the U.S. in the emerging postwar world-economy of capitalism was also important to these developments. The U.S. was able to consolidate its global political and economic power through the development of a variety of internationallyorientated institutional arrangements, currency and trade agreements, and the further militarization of its economy (Agnew, 1987; Wolfe, 1981). Under the Bretton Woods system, the dollar was elevated to the status of international currency and institutions like the World Bank and the International Monetary Fund were established to coordinate international flows of capital, finance, and loans to developing countries (Block, 1977). The General Agreement on Tariffs and Trade (GATT) functioned within this framework to establish a relatively stable trade regime. Marshall Aid provided a vehicle for the reconstruction of 


\section{RICHARD FLORIDA and ANDREW JONAS}

Western Europe and Japan and, in doing so, stimulated overseas demand for U.S. industrial products (Van der Pijl, 1984). In this context, corporations were able to impose a more stable set of industrial relations upon the domestic labor force through the "class accord".

Wartime mobilization had stimulated the militarization of the domestic economy and, facing respectively the loss of contracts and jobs consequent to demobilization, major industrialists and the industrial labor unions pressured the federal government into maintaining high levels of defense spending. This development was greatly aided by the Korean and Vietnam Wars, the military-strategic environment of foreign policy created by the Cold War), as well as the continued U.S. military presence abroad. Defense expenditures increased from $\$ 15$ billion, or $18 \%$ of the federal budget, in 1940 to $\$ 83.9$ billion (38\%) in 1950 , and $\$ 192$ billion $(50 \%)$ by 1960 (U.S. Office of Management and Budget, Historical Tables, 1986). Even though the multiplier effects of military spending were not as large as those to be gained from full employment Keynesian "social democracy", they offered a coherent substitute, along with more "conventional" forms of regulatory policy such as tax and monetary policy. Moreover, defense spending and other, related federal expenditures on infrastructure reinforced emerging decentralization trends in the U.S. space economy through the establishment of new "growth poles" in hitherto undeveloped parts of the country in the south and west. These decentralization tendencies significantly shaped the form and content of postwar urban policy.

\section{U.S. Fordism, Suburbanization, and Postwar Urban Policy Dynamics}

Suburbanization was a crucial spatial dynamic within the postwar political economy (Florida and Feldman, 1988; Walker, 1981). It was both a cause and a consequence of the cementation of Fordist social relations in the workplace, and it was shaped by the urban policy experiments of the New Deal. Although New Deal urban policy actually created the institutional framework for suburbanization, it was the closure of the more "social-democratic" elements of New Deal policy which made large scale suburban growth possible. Prompted by New Deal policies, suburbanization was propelled by a growing demand for housing, automobiles, consumer durables and public services (eg: education and infrastructure).

Increased federal expenditures on education and urban infrastructure helped subsidize suburban growth. The G.I. Bill (or Serviceman's Budget Act) of 1944 created the Veteran's Administration and made federal payments for housing and education available to some 16 million returning veterans, helping to bolster homeownership amongst the 
working classes and swell the student population of high schools and universities throughout the country. The postwar "baby-boom" brought further expansion to the U.S. education system. The Federal Highway Act of 1956 provided an additional impetus for suburban dispersal by creating an extensive, federally-financed (up to $90 \%$ of cost) and locallyimplemented freeway system within and between metropolitan areas. Urban infrastructure paved the way for suburban growth. Housing starts averaged approximately 1.5 million units per year over the immediate postwar period, and consumer expenditure for housing and transportation increased from $\$ 718$ to $\$ 2,513$ (constant dollars) per household between 1941 and 1961 (Florida and Feldman, 1988).

Suburbanization thus served as a "spatial fix" to the accumulation crisis of capitalism under a Fordist regime of accumulation/mode of regulation (Harvey, 1985: 204-207). Together with the rise of military spending, suburbanization eliminated the structural-economic "need" for extensive State intervention in the domestic economy in "socialdemocratic" forms similar to those that had occurred in West European countries after the war, where the trajectory of class struggle had shaped very different relations between the economy, civil society, and the State, including the territorial manifestation of those relations (Davis, 1986: 181-230; Walker, 1977; 1981).

Suburbanization gave a distinctive spatial character to Fordist social relations. There was a marked spatial decentralization of elements of the production process. This decentralization was made possible by technological changes at the point of production and changes in corporate organization. With it came a spatial fragmentation of labor markets, a process reinforced by the workings of the housing market. The postwar geography of metropolitan areas, while remaining functionally linked within corporate structures, became increasingly fragmented into a complex mosaic of industrial and commercially-orientated suburbs, and central cities transformed from centers of manufacturing employment to political and economic spaces dominated by a wide range of corporate, government, and service functions (Stanback and Noyelle, 1982).

All of these amplified the social divisions at the heart of postwar U.S. Fordism and brought about a fragmentation of the working class. Surrounding the unionized "core" of the labor market, was a "periphery" of low-paid, irregular, and erratic work (Gordon, Edwards and Reich, 1982). Segmented labor markets were reinforced by "dual" housing markets. New Deal housing policy innovations had put in place institutions which ultimately favored a growing white middle class and discriminated against the black inner-city poor and working classes. Consequently, the economic advantages of suburbanization accrued mainly to those who were full partners in the "class accord". Suburban homeownership meant equity rather than rent, appreciation, tax benefits, 
and superior bundle of local government services (especially, and most importantly, in the area of education), while 'peripheral' groups were relegated to inner-city housing markets and the marginal labor market and educational opportunities remaining there. Exclusionary zoning and housing discrimination also divided people along racial lines (Danielson, 1976; Jackson, 1985), and created a situation where older cities became the equivalent of residential "enclaves" or "reservations" for minorities and the urban poor (Hill, 1980). These dynamics were further reinforced by the fragmentation of metropolitan areas into multiple and independent political units (Teaford, 1986). Jurisdictional authority for such key government services as education and housing, and control over the local property tax base, became highly decentralized, often denying marginalized social groupings in central cities access to the apparatus of local government.

Decentralization put downward pressure on the local revenue base of urban municipalities (Scott, 1988), while expenditures in central cities escalated. Local governments were caught between competing demands for the metropolitan-wide provision of infrastructure and the delivery of social services to the central-city poor (Piven and Friedland, 1984). The result of these demands was a spatial mismatch of tax resources to needs across the metropolis, central-city fiscal strain, and eventually in a few cases outright municipal default (Cox, 1973; Tabb, 1982). The problems of fiscal stress were felt most acutely by cities in the north and east, whereas urban infrastructural development in the cities of the south and west was heavily subsidized by the federal government and many Sunbelt cities were able to capture a decentralizing tax base through annexation (Fleischmann, 1977; Mollenkopf, 1983; Jackson, 1985).

Suburban-orientated domestic growth also hastened the transformation of postwar housing policy. A report released in 1941, entitled Urban Redevelopment and Housing: A Plan for Postwar, had proposed the use of public housing as part of a broad program to rebuild cities, force important reforms in the housing sector, and lead at least in part toward full employment (Gelfand, 1975: 119-121). But the 1949 Housing and Urban Redevelopment Act ushered in the shift from public housing to urban renewal (Weiss, 1980; Friedland, 1983). The reasons for this shift had to do with transformations in class and territorial relations consequent to the consolidation of Fordism within the U.S. political economy. Together, the "class accord" and suburbanization conferred distinct material benefits on a significant portion of the working class, diluting the potential constituency for public housing. Just as importantly, the devastating effects of rapid suburbanization on central-city tax bases led to the emergence of what Mollenkopf (1975) refers to as "pro-growth coalitions" in many of the largest cities in the north and east which placed significant pressure on the federal government, especially the 
Democratic Party, to bolster central-city tax bases through slum clearance and urban renewal (Mollenkopf, 1983; Weiss, 1980). Thus these transformations in housing policy ran parallel to the shift in fiscal policy away from full employment and Keynesian "social democracy".

Amendments to the original 1949 Housing Act systematically diluted recruitments that inner-city redevelopment projects include significant levels of public housing (Foard and Fefferman, 1966; Weiss, 1980). Low income-housing policy thus became ensconced in a program for revenue enhancement through commercial revitalization. Complicating this, the high cost of land assembly in central locations and the stipulation that public housing had to replace existing housing led to the construction of high density projects within designated urban renewal areas. Public housing was inadequate to meet the needs of city dwellers and became synonymous with undesirable housing.

\section{New Deal Closure and Great Society}

The "Great Society" can only be understood within the context set by the closure of the New Deal and the simultaneous development of systematic contradictions inherent in the U.S. variant of the Fordist model of economic growth. Although most commentators recognize the importance of social struggles in setting the stage for the tremendous increase in federal urban policies and programs in the 1960s, there is still a tendency to view the Great Society either as a direct federal political strategy to gain new votes and to rebuild a "New Dealist" Democratic urban constituency after a decade of Republican electoral successes (Caraley, 1976; Mollenkopf, 1983), or as a program for quelling social unrest amongst people left out of postwar economic growth and redistributing the benefits of that growth to marginalized groups (ie: "regulating the poor"; Piven and Cloward, 1971). These arguments underestimate the structural political-economic conditions which underpinned the social struggles, partisan shifts, and urban policy experiments of the Great Society era.

The emergence of the Great Society was tied at bottom to the uneven development and deep socio-economic divisions of the postwar U.S. political economy. It was these divisions which provided the impetus for intense political mobilization by social groups marginalized by the postwar "class accord". Postwar economic growth had created certain unrealized expectations amongst people who had for a long time experienced economic dislocation, social deprivation, and/or racial discrimination, resulting in an angry backlash.

The earliest - and most important - struggles occurred mainly in the rural south, although these struggles quickly spread to the cities of both 
the south and the north. Mechanization of Southern agriculture, and large-scale rural public works projects initiated in the depression resulted in the massive displacement of black households from their land and farms, placing considerable pressures on labor markets in the larger, industrialized urban centers in the south. Within those cities, and throughout the south, protests over segregated municipal services, "Jim Crow" petty discrimination, unequal educational opportunity, and discrimination in employment erupted on a large scale, and lasted from the mid-1950s to the early 1960s (Piven and Cloward, 1977: 181-263). These protests prompted a violent backlash among working-class southern whites, forcing the federal government eventually to intervene through the deployment of the military and law enforcement officers, and through legislation which attempted limited improvements in civil rights for blacks in the south. Landmark civil rights decisions by the U.S. Supreme Court had major impacts within the urban policy area, especially in the areas of education and the minority hiring practices of municipal governments. The 1954 decision in Brown versus Board of Education, that racial segregation of schools is unconstitutional, was followed by further rulings which called for the desegregation of urban school districts, and the eventual implementation of highly controversial and unpopular busing programs.

The relocation of a large percentage of the black population to the established industrial centers of the north and east both created centralcity "reservations" for racial minorities and provided an important source of support for the growing southern movement. Mobilization in the north enabled the civil rights movement to broaden its demands from civil rights in the electoral sphere and equal access to services to demands for economic improvement. Multinational industrial interests also supported civil rights legislation under the Kennedy and Johnston Administrations (Ferguson and Rogers, 1986: 54-56).

The explosion of political and social unrest in the northern cities in 1966 and 1967 was a critical factor underlying the rapid expansion of direct federal urban policies in the mid-1960s and early 1970s. If the high concentration of marginal groups provided an underlying cause of this explosion, many specific incidents were related to the abuses of past federal policies such as urban renewal which had resulted in the widespread devastation of inner-city neighborhoods (Isaac and Kelly, 1981; Wilson, 1980: 134-139).

The new urban policy of the 1960 s occurred at a variety of levels. The Civil Rights Acts of 1964 and 1968 provided formal legal protection for blacks against overt racial discrimination in labor and housing markets, while the Voting Rights Act of 1965 reaffirmed the rights of blacks to participate fully in electoral politics. Under the Economic Opportunity Act of 1964, the Office of Economic Opportunity was created largely as 
a vehicle for neighborhood-based economic development within the major central cities. This agency oversaw a wide variety of new programs which focused to some degree on the socio-economic and spatial ramifications of marginalization and racial discrimination, and provided an opportunity for career-advancement for well-educated and professionally-trained minorities. A significant share of the funding for these programs by-passed city halls and the New Deal urban agencies, and went directly to neighborhood groups. This brought about substantial opposition from municipal officials who saw their power base being undercut - in some cases, entire black electoral constituencies were threatened - and generated significant obstacles to program implementation (Moynihan, 1969). The Model Cities program made an additional $\$ 2.3$ billion in federal funds available for comprehensive, neighborhood-based community development (Frieden and Kaplan, 1975).

Partly as a consequence of the backlash from big-city mayors who wanted funds redirected from neighborhood groups to city hall, the Great Society also saw a dramatic upsurge in traditional "bricks and mortar" programs such as urban renewal and highway construction aimed at the economic revitalization of central cities (Holcomb and Beauregard, 1981). Further amendments to the 1949 Housing Act saw an increase in the proportion of slum clearance and urban renewal to underwrite commercial and public reinvestment in downtowns rather than low-income housing. The Urban Mass Transportation Act of 1964 made grants available to localities for the improvement of public transit services. In 1965, the new Department of Housing and Urban Development (HUD) was established to coordinate federal housing policies in the cities. Its enabling legislation made an additional $\$ 3$ billion available for urban renewal and public housing. The 1968 Housing Act expanded federal funding both for public housing and urban renewal, and it added two new federal housing programs, Sections 235 and 236, which provided interest rate subsidies for low-income homeownership and multifamily rental housing respectively (Aaron, 1972; Hartman, 1975). An annual average of 80,000 public housing units were built between 1968 and 1971 (Bratt, 1986).

Income-maintenance programs expanded significantly during the 1960 s and the early 1970 s as a way to placate urban unrest. The Food Stamp program expanded from 400,000 recipients in 1965 to more than 20 million a decade later. Largely in response to burgeoning social unrest and the mobilizations sponsored by the National Welfare Rights Organization (NWRO), the Johnson Administration extended relief benefits in a series of 1965 amendments to the Social Security Act (Piven and Cloward, 1977: 264-361; Page, 1983), establishing Medicare and Medicaid, and liberalizing the formula for obtaining Aid to Families with 


\section{RICHARD FLORIDA and ANDREW JONAS}

Dependent Children (AFDC) (Advisory Committee on Intergovernmental Relations, 1980). AFDC funding increased from $\$ 1$ billion in 1965 to over $\$ 4$ billion in 1975, although benefit levels varied significantly from place to place. In 1981, for example, average benefits varied from $\$ 147$ per month in California to just $\$ 29.83$ in Mississippi (Page, 1983: 60-100).

Social unrest also led to a rapid rise in federal law enforcement assistance to local police departments. The Office of Law Enforcement Assistance, established in 1965, and the Omnibus Crime Control and Safe Streets Act of 1968 made billions of dollars available to local law enforcement agencies increasing the size and effectiveness of the "occupying armies" of police in low income, mostly minority, urban neighborhoods (Feeley and Sarat, 1980).

All in all, federal aid to urban areas and to disadvantaged groups in cities rose dramatically throughout the 1960s and early 1970s. Tables 2 and 3 chart the parameters of this increased State intervention. The share of the budget comprised of social expenditures nearly doubled over these 15 years, increasing from $28 \%$ to $52 \%$, with social security and income maintenance expenditures making up the largest components of this increase (Table 2). Federal direct aid to individuals doubled between 1960 and 1970, increasing from $\$ 65.7$ billion to $\$ 132$ billion, and by 1975 had reached $\$ 237.3$ billion, or $40 \%$ of all federal outlays (Table 3 ). In addition, federal grants to state and local governments expanded even more rapidly. The number of grant programs grew from just 40 in 1960 to more than 500 by 1970 , while total funding increased from $\$ 24.7$ billion to $\$ 61.2$ billion over the same period. Between 1965 and 1970, the share of municipal revenue coming from intergovernmental sources increased from $22 \%$ to $30 \%$, and by 1978 , the share of intergovernmental revenue for all cities hit roughly $40 \%$. By this time, large cities, especially those in the north and east, were receiving more than half their revenue from intergovernmental sources, creating a relatively high degree of "intergovernmental dependence" (Burchell et al., 1984).

Despite such dramatic increases, the Great Society was fully bounded by the closure of the New Deal. There was no attempt to build new institutions or sets of social relationships designed to address the structural roots of income poverty and unemployment. The terms of the "class accord" confined State intervention to the provision of public services, limited expansion of public employment and the guarantee of formal legal equality and civil rights to minorities. Since direct intervention into the relations of production was regarded as "off limits" under the terms of the "accord", federal policies of income redistribution used rather circuitous routes such as nursery schools (Project Headstart) and health care subsidies (Medicaid) to fight poverty. Furthermore, a significant share of urban aid went toward areas which would not solve 
Table 2 Federal Expenditure by Major Function, 1960-1985 (billions of dollars)

\begin{tabular}{|c|c|c|c|c|c|c|}
\hline & 1960 & 1965 & 1970 & 1975 & 1980 & 1985 \\
\hline Total & 92.1 & 118.2 & 195.7 & 332.3 & 590.9 & 946.3 \\
\hline Defense & $\begin{array}{c}48.1 \\
(52.2)\end{array}$ & $\begin{array}{c}52.6 \\
(42.8)\end{array}$ & $\begin{array}{c}81.7 \\
(41.8)\end{array}$ & $\begin{array}{c}86.5 \\
(26.0)\end{array}$ & $\begin{array}{l}134.0 \\
(22.7)\end{array}$ & $\begin{array}{l}252.7 \\
(26.7)\end{array}$ \\
\hline \multicolumn{7}{|l|}{ Human } \\
\hline $\begin{array}{l}\text { Resources/ } \\
\text { Social Services }\end{array}$ & $\begin{array}{c}26.2 \\
(28.4)\end{array}$ & $\begin{array}{c}36.6 \\
(31.0)\end{array}$ & $\begin{array}{c}75.3 \\
(38.5)\end{array}$ & $\begin{array}{l}173.2 \\
(52.1)\end{array}$ & $\begin{array}{c}313.4 \\
(53.0)\end{array}$ & $\begin{array}{l}471.8 \\
(49.8)\end{array}$ \\
\hline $\begin{array}{l}\text { - Education/ } \\
\text { Training }\end{array}$ & 1.0 & 2.1 & 8.6 & 12.5 & 31.8 & 29.3 \\
\hline $\begin{array}{l}\text { - Health/ } \\
\text { Medicare }\end{array}$ & 0.8 & 1.8 & 12.1 & 20.3 & 55.3 & 99.5 \\
\hline $\begin{array}{l}\text { - Social } \\
\text { Security }\end{array}$ & 11.6 & 17.5 & 30.3 & 55.9 & 118.6 & 188.6 \\
\hline $\begin{array}{l}\text { - Income } \\
\text { Maintenance }\end{array}$ & 7.4 & 9.5 & 15.6 & 33.7 & 86.5 & 128.2 \\
\hline Other* & $\begin{array}{c}17.8 \\
(19.4)\end{array}$ & $\begin{array}{c}31.0 \\
(26.2)\end{array}$ & $\begin{array}{c}38.7 \\
(19.7)\end{array}$ & $\begin{array}{l}72.6 \\
(21.8)\end{array}$ & $\begin{array}{l}143.5 \\
(24.3)\end{array}$ & $\begin{array}{l}221.8 \\
(23.4)\end{array}$ \\
\hline
\end{tabular}

Numbers in parentheses represent percentage share of total.

- Other includes physical resources, net interest, international affairs, science, agriculture, justice and general government functions.

Source: Office of Management and Budget, Historical Tables of the Budget of the U.S. Government, Fiscal Year 1987 (Washington, D.C., 1986), Table 3.1.

Table 3 Trends in Federal Expenditures, 1940-1985

(in billions of constant 1982 dollars)

\begin{tabular}{lcccccccc}
\hline & 1940 & 1950 & 1960 & 1965 & 1970 & 1975 & 1980 & 1985 \\
\hline Total & & & & & & & & \\
Outlays & 83.2 & 220.5 & 340.4 & 394.9 & 569.4 & 586.0 & 699.1 & 846.1 \\
$\begin{array}{l}\text { Direct aid to } \\
\text { Individuals }\end{array}$ & $\mathbf{9 . 6}$ & 47.5 & 65.7 & 82.3 & 132.0 & 237.3 & 287.3 & 337.7 \\
$\begin{array}{l}\text { Grants to } \\
\text { State/Local }\end{array}$ & 7.4 & 10.4 & 24.7 & 35.4 & 61.2 & 87.1 & 105.9 & 93.5 \\
Government & $(9.2)$ & $(5.5)$ & $(7.3)$ & $(9.2)$ & $(12.3)$ & $(15.0)$ & $(15.5)$ & $(11.2)$ \\
Defense & 15.1 & 83.9 & 192.1 & 181.4 & 225.6 & 159.8 & 164.0 & 226.7 \\
& $(18.1)$ & $(38.0)$ & $(56.4)$ & $(45.9)$ & $(44.3)$ & $(27.3)$ & $(23.5)$ & $(26.8)$ \\
& & & & $(20.8)$ & $(25.9)$ & $(40.1)$ & $(41.1)$ & $(39.8)$ \\
\end{tabular}

Note: Numbers in parentheses represent percentage shares of total.

Source: Office of Management and Budget, Historical Tables of the Budget of the United States, Fiscal Year 1987 (Washington, D.C., 1986) Table 6.1. 
the underlying problems of cities at all; "bricks and mortar" programs displaced city residents, and law enforcement programs increased the "means of repression" available to local authorities.

The Great Society was not a fundamental shift in the institutional arrangement of the U.S. political economy because it could not be so, being fully bounded by the narrow institutional parameters set down by the closure of the New Deal. Instead of attacking the real causes of postwar social division and uneven development, it attempted to redistribute the benefits of postwar growth to the social and geographical spaces left behind by that growth, and grant marginalized groups limited participation in the "class accord". As such, it constituted a potential "neoFordist" solution, increasing the incomes and hence the effective demand of disadvantaged groups without actually transforming the social relations of mass production (Davis, 1986: 201). Within this context, Great Society also helped the Democratic Party reconsolidate its electoral base in northern cities and "buy votes" (Mollenkopf, 1983). But given the existing levels of intra-metropolitan segregation and political fragmentation, this redistribution took place largely within the working class, often pitting blacks against whites. State intervention was limited to bolstering the conditions for capital accumulation, while providing some marginal assistance to disadvantaged groups in the context of greater social control. But even in this regard, the form and content of the urban policy programs of the 1960 s proved too anemic to stimulate economic growth and move the economy forward.

\section{The Accumulation Crisis of U.S. Fordism}

The Great Society years saw serious signs of stress emerging in the postwar political economy, symptomatic of contradictions lying at the heart of U.S. Fordism. The period stretching from the mid-1960s to the early 1970s witnessed a growing accumulation crisis. Most of the major refinements in Fordist production methods had been achieved by the mid-1960s and it became harder to realise productivity increases by further subdividing tasks along the assembly line (Aglietta, 1979; Blackburn, Coombs and Green, 1985). After averaging 3.2\% between 1948 and 1966 , annual growth in productivity, or hourly output fell to $2.3 \%$ between 1966 and 1973, and 1.1\% between 1973 and 1979, before turning negative in the late 1970s and early 1980s (Bowles and Gintis, 1982). At the same time there was a significant slowdown in the rate of growth in per capita Gross National Product from an average annual increase of $2.6 \%$ p.a. between 1960 and 1970 to $1.6 \%$ between 1970 and 1982 .

Productivity problems were compounded by a "profit squeeze" caused by the interaction of tight labor markets, increasing worker 
militancy, burgeoning social unrest, and rising public expenditures, together with increased public indebtedness for defense and social programs. As Bowles and Gintis (1982) have shown, the business share of total output declined from $37 \%$ to $29 \%$ between 1955 and 1972, while the workers' share rose proportionately, with the most significant component of the rise in workers' share accounted for by the expansion of the social wage. The combination of declining productivity and the "profit squeeze" resulted in sharp declines in corporate profitability, which for non-financial corporations fell from approximately $15 \%$ p.a. between 1948 and 1965 to $10 \%$ during the 1970 s.

The economic crisis fed back into overall economic conditions and affected wages, income and demand. In the short run, corporations responded to increased worker militancy and the "profit squeeze" simply by translating higher wage claims into higher prices, setting off a tenacious inflationary spiral (Bowles, Gordon and Weisskopf, 1986). In the long run, however, large corporations attempted to bolster profit levels and dividend shares by reducing labor and other production costs through relocation to non-unionized low-wage regions, automation and technological change, intensification of work tasks, and/or direct assaults on wages (Harrison, 1984). After increasing rapidly through the 1950 s and the 1960s, the real after-tax earnings of American workers began to decline in 1972 and by 1981 had fallen back to their lowest levels since the early 1960s (Scott, B.R., 1985).

Developments in the world economy provided little succor from domestic economic problems. Competition from West Germany, Japan, and the Newly Industrializing Countries (NICs) of South East Asia, combined with the economic power of the oil-producing (OPEC) countries, significantly undermined postwar U.S. political and economic hegemony. This was dramatically demonstrated by the withdrawal of the dollar from the gold standard in 1972 (Block, 1977). Trade problems mounted for the U.S.: imports as a proportion of GDP quadrupled in 1960 and 1979, and the manufacturing trade balance turned negative in 1971 and continued along a downward trajectory for the course of the next decade (Scott, B.R., 1985). The two "oil shocks" of the 1970s resulted in significant increases in the prices of petroleum-related products which accelerated inflation and called suburban growth into question.

The crisis was also linked to the consumption structure of U.S. Fordism. Inflation and worsening cyclical volatility became endemic to housing markets, and declining wages forced households to divert larger shares of income to housing consumption, thereby reducing demand for consumer goods. For example, automobile registrations peaked at 75 per 1000 in 1965 and declined to 46 per 1000 by 1982, and markets for electronics goods and home appliances also saw similar contractions (Feldman 
and Florida, 1989). This called into question the productivity-wageconsumption nexus which had provided the structural undergirding of postwar growth.

\section{Economic Crisis, Territorial Adjustment and the Transformation of Urban Policy}

The economic crisis of U.S. Fordism carried with its major spatial adjustments manifest with the new spatial division of labor characterized by a relocation and dispersal of corporate functions on a global scale (Clark, 1981; Cohen, 1981; Froebel et al., 1980; Hymer, 1972; Massey, 1984). This in turn ultimately shaped a redefinition of urban policy.

Decentralization towards the suburbs and Sunbelt (Sternlieb and Hughes, 1975; Perry and Watkins, 1977; Dilger, 1982) significantly affected U.S. electoral politics mainly because it altered the composition of both elite and electoral constituencies at the regional level. This "regional politics" was perhaps most clearly reflected in the rise of Nixon's "New Federalism", the basic objective of which was to consolidate political support for the Republican Party by shifting federal funds to growth areas in the south and west (Phillips, 1970). The New Federalism sought to bypass traditional Democratic strongholds in the older cities and regions by channelling funds directly to states for local redistribution. The two centerpieces of the New Federalism were the General Revenue Sharing (GRS) and Community Development Block Grant (CDBG) programs whereby funds were allocated to cities by formula with very few conditions attached. In many cases, funds were conditional upon the creation of more jurisdictionally-encompassing governmental entities for metropolitan areas, thereby undermining the powers of local government and allowing regional corporate interests to gain greater control over the distribution of funds for urban economic development (Feshback and Shipnuck, 1973).

The shift from categorical to block grant funding also weakened the position of older cities in the framework of intergovernmental relations. Categorical funding under Great Society tended to benefit older cities and their Democratic constituencies both because they could best demonstrate need and because they developed the expertise necessary to steer applications through federal agencies. With block grant funding, the distribution of federal funding was pegged to formulae whose costs and benefits for various classes of cities could be easily predetermined. Regional coalition-building and "print-out politics" now superseded traditional patterns of legislative log-rolling (Markusen et al., 1981). Block grant funding thus became a direct reflection of the balance of political forces at the regional level and the political bargains struck among them, and it became very difficult to re-target aid to older cities. 


\section{U.S. URBAN POLICY 373}

There was an abortive attempt by the Carter Administration to reverse the spatial trajectory of Nixon's New Federalism. Federal funding under Carter was targetted directly to neighborhood-based groups in the cities. But these urban policy experiments were bound by the changing politics of federal spending and worsening economic conditions. For example, the debate over the renewal of the CDBG program became engulfed in sectional politics, pitting Frostbelt against Sunbelt political interests in the establishment of a new funding formula. The eventual outcome of this battle was the establishment of a compromise, or dual formula system, where cities could choose between the original Nixon formula and a new formula weighted slightly in favor of the older cities (Caraley, 1978; 1979; Dilger, 1982).

More importantly, Carter's experiments in developing an explicit urban policy became caught up in the worsening crisis of U.S. Fordism. Put simply, contradictions internal to the postwar growth model translated increasingly into contradictions within the State itself as reflected in fiscal crises at both the federal and local levels (cf. O'Connor, 1973). Thus Carter's federal urban policy was quickly set aside after 1978 in the interests of resolving budgetary problems at the federal level and the accumulation crisis of capital. As Figure 1 shows, real urban outlays as a percentage of federal expenditures peaked at $12.4 \%$ in 1978 and began a steady decline thereafter. The final years of the Carter Administration saw the initiation of a number of shifts in federal policies which later became a hallmark of the Reagan years, including increased defense spending, financial deregulation, and the imposition of monetarist measures.

\section{The "Destructuring" of Urban Policy in the 1980s}

It is often claimed that the Reagan years marked the end of an explicit urban policy for America's cities and, to that end, were witness to the dismantling of the New Deal. While it is convenient to "blame" the Reagan Administration for attempting to dismantle postwar urban policy, such a conclusion obscures more than it uncovers. The Reagan Administration merely accelerated the trend towards reduced federal expenditures on the cities initiated under Carter.

Reagan's implicit urban policy was the use of budgetary measures to bring about the elimination or redirection of federal spending on urban social programs, privatization of government services, tax cuts, deregulation, and increased defense spending. These measures were part of a broader program to reinvigorate the domestic political economy and to build new institutional arrangements with which to manage a new structural phase of capitalist growth. Thus, the Reagan years can be best 
Figure 1 Real Urban Outlays as a Percent of Federal Expenditures *, 1967-1984.

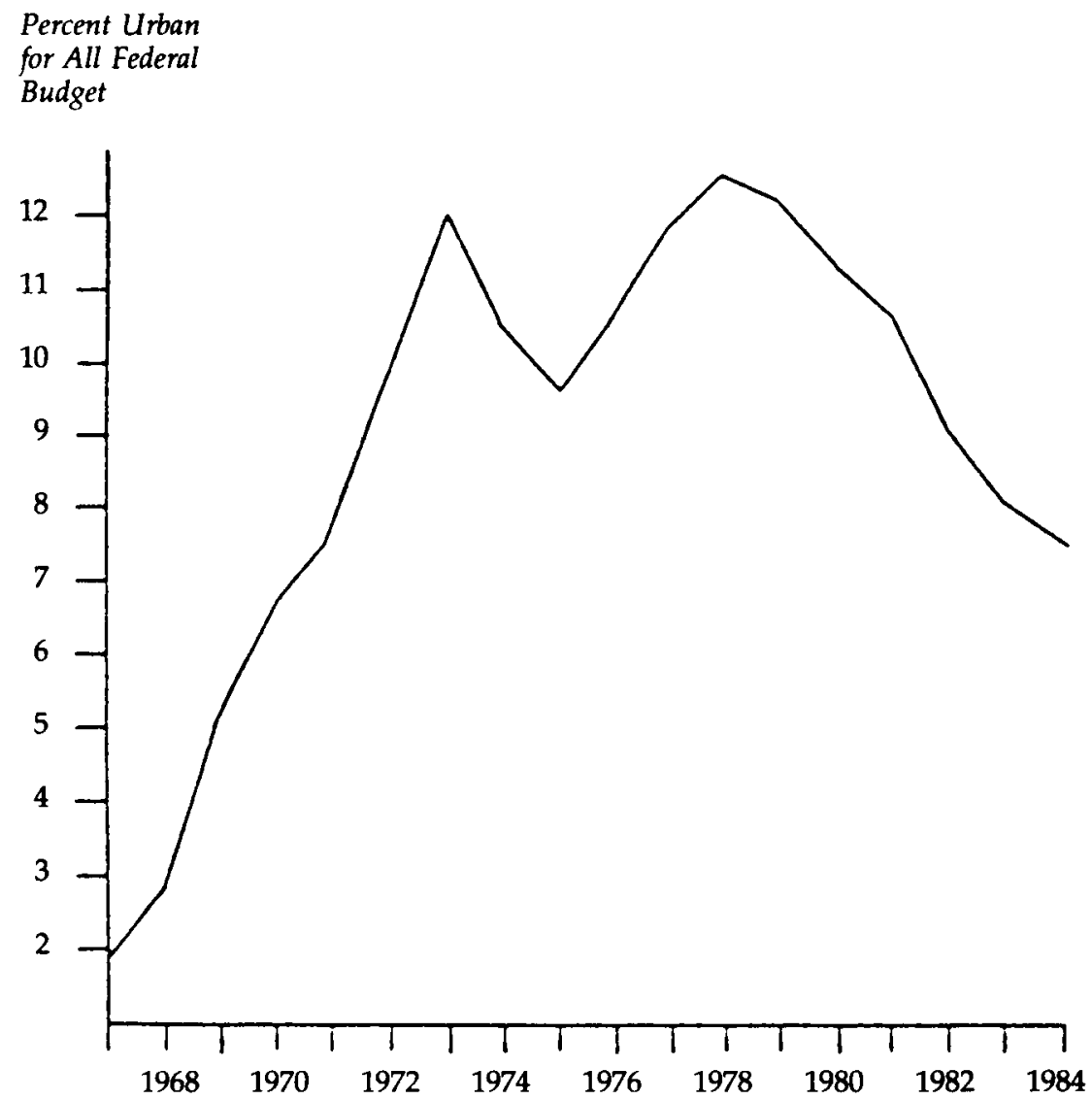

*Note: Real urban outlays are based upon a data base compiled by Glickman (1985) on highly targetted urban-oriented programs.

Source: Norman Glickman, "Cities in the International Division of Labor," Lyndon B. Johnson School of Public Affairs, University of Texas, Austin, Working Paper No. 31, (1985).

understood as a set of experiments in political-economic "destructuring" based on selective elimination or redirection of the income-maintenance and social programs of Great Society, the re-routing of federal spending from Democratic constituencies in the older cities to Republican strongholds, a transfer of administrative responsibility from the federal government to states and localities, and an overall reduction of the social wage.

Budgetary policies became the primary vehicle for this "destructuring". The Omnibus Reconciliation Act of 1981 and subsequent budgetary 
measures resulted in very severe cuts in urban social programs including education, job training, unemployment, income maintenance, food stamps, and social services (U.S. Office of Management and Budget, 1982; 1986). Many programs which either originated in, or expanded rapidly under, the Great Society were the hardest hit, with $\$ 1.1$ billion cut from the Medicaid program in fiscal year 1982, $\$ 1.7$ billion from the foodstamp program, $\$ 1.2$ billion from AFDC, $\$ 400$ million in energy assistance to individuals, and $\$ 200$ million in unemployment insurance (Nathan et al., 1982; Piven and Cloward, 1982: 16-19). Both the CETA program and GRS were eventually eliminated, and the CDBG program experienced significant reductions. In terms of housing, near exclusive reliance was placed on the Section 8 program which provides rent supplements to renters of private housing. Both this program and public housing saw major cuts as well. Between 1981 and 1985, expenditures on income-maintenance and other social programs declined by at least $10 \%$, at the same time as defense expenditures increased sharply (Ferguson and Rogers, 1986: 124-130).

The Reagan Administration sponsored a second "New Federalism" in which 62 categorical grants were eliminated and an additional 57 were consolidated into 7 block grants (Glickman, 1984). Total grants fell from $\$ 105.9$ billion ( $15.5 \%$ of all federal outlays) in 1980 to $\$ 93.5$ billion (11.2\%) in 1985. The Reagan fiscal program, like Nixon's in the early 1970s, resulted in more or less targetted redirection of federal funds to cities in the south and west. According to research by Muller (1982) and Glickman (1984), Reagan fiscal and monetary policies had clear regional impacts. A one hundred point index developed by Glickman (1984), incorporating the fiscal effects of cuts in taxes and social programs and increased defense expenditures, shows that the Pacific (217), New England (164) and West South Central (145) regions were the major gainers. Losers included the Middle Atlantic (58), East North Central (62), and West North Central (53) regions.

Budget reductions most seriously affected disadvantaged groups in cities, with the urban poor bearing the brunt of fully half the budget reductions during Reagan's first term (Center on Budget and Policy Priorities 1984; 1985; Nathan, 1983). Annual benefits from AFDC and foodstamps plummetted from a peak of $\$ 8,743$ for a four person family in 1972 to $\$ 6,955$ in 1984 . Largely as a consequence of this, the number of people estimated to be below the poverty line increased from 24 million in 1978 to more than 33 million by 1984 (see Harrison, Tilly and Bluestone, 1986). These austerity measures were imposed upon people already disciplined by the program cuts of the 1970s.

Put in its proper historical context, the Reagan Administration attempted to use the powers of the State to dismantle some of the primary political-economic institutions of the postwar era. But rather than at- 
tempting to create a new environment of capitalist regulation within which to build a new regime of accumulation, the Reagan era sought to reconstitute the relations of capital to wage labor to generate profit. In this sense, the lowering of the social wage and increased poverty was not an unintended byproduct of "destructuring" but its desired objective. State intervention exacerbated the declining overall standard of living produced by falling real wages and brought about a reduction in the number of quality employment opportunities in private sector labor markets. What conservative commentators like Murray (1984) claim was the result of increased public intervention was in reality due to worsening economic dislocation and an anemic federal response to it. By the same token, the "new class war" (Piven and Cloward, 1982) was more than simple Reaganomics; it was the product of a decade or more of capitalist response to the crisis of U.S. Fordism and of policy directions begun under Carter. Recent trends in domestic policy have compounded the structural weakness of the U.S. political economy and have contributed to its continued unraveling.

\section{The Future Direction of Urban Policy}

In this essay, we established a theoretical framework within which to situate federal urban policy. Drawing upon regulationist theory and recent contributions to a theory of the State, we demonstrated how the form and content of urban policy in the New Deal was shaped by the rise of mass-production Fordism and emerged from the political struggles of the Great Depression era. As a result of these struggles, and in the context of the "class accord", the postwar period saw a limited and constrained mode of State intervention in the economy. In the realm of urban policy, this restricted level of State intervention set limits on further rounds of State policy and left the U.S. State unable to respond effectively to the mounting crisis of U.S. Fordism in the 1970s and 1980s, thus contributing to the "failure" of urban policy.

While this essay does not pretend to provide easy answers to the future of urban policy, it does provide a way to begin to think about the future possibilities. The combination of worsening economic crisis (the regime of accumulation) and the failure of social, political and economic institutions (the mode of regulation) have opened the "space" for a new period of policy experimentation and institution-building. The recent past has clearly entailed tremendous social costs which must be addressed. Escalating problems of homelessness are compounded by growing numbers of the potentially homeless (Angel, 1989). Rapid economic restructuring and rampant gentrification has actually led to the expulsion of the homeless from some downtown areas (Mair, 1986) 
and escalating social unrest and outright racism in others (Smith, 1989). Many inner-city areas have become virtual "war zones" in which drug trafficking and gang warfare are now regarded as commonplace (see Wilson, 1985). These developments are occurring in the very backyards of political leaders who seem incapable or unwilling to respond in a constructive manner, and indeed are caught up in the corruption themselves (witness the HUD scandal). With "kindler and gentler" force, the present Bush Administration and the Supreme Court are systematically causing the reversal of some of the most important urban policy decisions associated with the Civil Rights era, while the "war on drugs" is much more a political move to increase the size and extent of law enforcement and the courts in the cities than to address the serious drug problem which pervades large U.S. cities and U.S. society at large.

The current era provides an opportunity for political mobilization aimed at building more democratic institutions to manage the political economy and overcome social and racial divisions. For the most part, scholars have focused on understanding the new forms of technological and production organization which are currently emerging in the networked production districts of the U.S. and Western Europe as possible models for a new institutional framework for the political economy (Piore and Sabel, 1984; Scott and Storper, 1987). This work has neglected the complementary dimension of State policy and domestic political and economic institution building. Forecasting what types of policies and/or institutions can or should be created is a difficult business. Still, it is possible to fashion a few rough approximations and guesses.

New institutional forms will be forced to address the worsening income poverty and wage polarization that currently characterizes the U.S.. There is a muted but nonetheless visible political force emerging in and around urban areas as evidenced in Jesse Jackson's 1988 Presidential campaign. The precise articulation of political struggle will of course determine how this occurs but here possibilities include: raising the minimum wage, higher wage floors, tenure guarantees and/or creating public subsidies for housing, health and transportation. Neither the growth of flexible production districts nor the increased state and local action will be sufficient to create the massive phase of institution building which is needed to rebuild both the U.S. economy and U.S. society, especially at the urban level where many problems are most acutely felt. One obvious place to obtain the resources to do this is from defense; in the wake of current events in Eastern Europe, real "deep" cuts in defense appear politically feasible.

It is also worth commenting on the respective roles federal, state, and local governments might play in new urban policy initiatives. Such initiatives must maximize democratic participation. Administration could be accomplished at the local, even neighborhood level, even while 


\section{RICHARD FLORIDA and ANDREW JONAS}

resources are collected and dispersed centrally by the federal government. Democratic participation at the local level should be encouraged so that the program abuses that characterized the Great Society are minimized, and that funds are channeled to the people and institutions for which they are intended. States and localities have made important strides here during the lean years of the Reagan and Bush Administrations, but they absolutely cannot do it alone. In fact, states and localities have found it increasingly difficult to assume the increased fiscal burdens that have fallen upon them in the areas of education, housing, healthcare, and infrastructure, a problem compounded by a series of devastating middle class tax revolts in the 1970s and early 1980 s, as well as the limited borrowing capacity of local government.

Finally, we must note that the driving force in any refashioning of State intervention and urban policy will require progressive political action on a mass scale. Although the "door" is open for such action, mass political mobilization is necessary to motivate State action to refashion or to build new social and economic institutions. These "solutions" cannot be imposed from above like some deus ex machina, but as always must be borne out of the historical and spatial realities of political struggle. Here, the political movement and individuals crystallized around Jesse Jackson's 1988 campaign remain a ray of hope. And, it remains to be seen whether or not the rise of these and other progressive political coalitions can turn themselves into the force needed to push such efforts into motion at all levels in the State and U.S. society.

\section{Acknowledgements}

The authors thank Mark Garner for his generous comments. Special thanks are due to Marshall Feldman and Martin Kenney for helping to inform many of the ideas expressed herein. Thanks are also due to Gordon Clark, Kevin Cox, Andy Mair, Peter Marcuse and Richard Walker, and reviewers for their comments. Gordon Davidson provided research assistance. The authors hold equal responsibility for this article and remain jointly responsible for any errors.

\section{Note}

1. Some interpretations of New Deal urban policy place great emphasis on the idea that the urban policy experiments of this period were simply part of an attempt by the Democrats to forge a new electoral coalition based on urban ethnic and minority groups, and big city political and economic forces (see Mollenkopf, 1983). While recognizing the importance of this urban constituency to the Democratic Party's electoral successes in the depression and even afterwards, we argue that it was the structural economic crisis which actually opened up the "political-economic space" which made this coalitionbuilding possible. Indeed, much of the New Deal's more "social democratic" elements were a direct response to class struggles in the cities and were a 
means to control unrest. Interestingly, postwar growth greatly diffused the class character of social conflict, leaving big city Democratic mayors and their administrations as the most vocal advocates of the continuation of specific federal urban policy programs after the war. Ferguson (1984) shows that multinational industrial interests and large financial institutions shifted their positions on a number of crucial issues throughout the depression, allowing this electoral realignment to come in motion.

\section{References}

Aaron, H.J. (1972) Shelter and Subsidies: Who Benefits from Federal Housing Policies? Washington, D.C.: Brookings Institute.

Aglietta, M. (1979) A Theory of Capitalist Regulation. London: New Left Books.

Agnew, J.A. (1987) The United States in the World Economy: A Regional Geography. New York: Cambridge University Press.

Angel, D.P. (1989) Housing deprivation in Worcester. Lecture presented to the Graduate School of Geography, Clark University, November.

Barocci, T. (1979) Public Works Programs in the United States from FDR to the Present. New York: Praeger.

Berkowitz, E. and K. McQuaid (1980) Creating the Welfare State: The Political Economy of Twentieth-Century Reform. New York: Praeger.

Bernstein, I. (1970) The Turbulent Years: A History of the American Worker, 1933-1941. Boston: Houghton Mifflin.

Blackburn, P., R. Coombs, and K. Green (1985) Technology, Economic Growth and the Labor Process. New York: St Martin's.

Block, F. (1977) The Origins of International Economic Disorder. Berkeley: University of California Press.

Bonefeld, W. (1987) Reformulation of state theory. Capital and Class 33(Winter): 96-128.

Bowles, S. (1982) The post-Keynesian capital-labor stalemate. New Left Review 65(September-October): 45-72.

Bowles, S. and H. Gintis (1982) The crisis of liberal democratic capitalism: the case of the US. Politics and Society 11(1): 51-94.

Bowles, S., D. Gordon, and T. Weisskopf (1986) Power and profits: the social structure of accumulation and the profitability of the postwar US economy. Review of Radical Political Economics 18(1-2): 132-167.

Bratt, R. G. (1986) Public housing: the contribution and the controversy. In R.G. Bratt, C. Hartman, and A. Meyerson (Eds.) Critical Perspectives on Housing. Philadelphia: Temple University Press.

Brody, D. (1980) Workers in Industrial America: Essays on the 20th Century Struggle. New York: Oxford University Press.

Burchell, R.W., J. Carr, R. Florida, and J. Nemeth (1984) The New Reality of Municipal Finance: The Rise and Fall of the Intergovernmental City. New Brunswick, NJ: Center for Urban Policy Research.

Caraley, D. (1976) Congressional politics and urban aid. Political Science Quarterly 91(Spring): 312-338.

Caraley, D. (1978) The Carter Congress and urban programs: first soundings. In W.D. Burnham and M. Weinberg (Eds.) American Politics and Public Policy. Cambridge: MIT Press.

Center on Budget and Policy Priorities (1984) End Results: The Impact of Federal Policies Since 1980 on Low Income Americans. Washington, D.C.: Interfaith Action for Economic Justice. 


\section{RICHARD FLORIDA and ANDREW JONAS}

Center on Budget and Policy Priorities (1985) Smaller Slices of the Pie. Washington, D.C.: Interfaith Action for Economic Justice.

Chandler, A.D. (1977) The Visible Hand: The Managerial Revolution in American Business. Cambridge: Harvard University Press.

Clark, G.L. (1981) The employment relation and the spatial division of labor: a hypothesis. Annals of the Association of American Geographers 71(3): 412-424.

Clarke, S. (1983) State, class struggle, and the reproduction of capital. Kapitalistate 10/11: 113-130.

Clarke, S. (1988) Overaccumulation, class struggle and the regulation approach. Capital and Class 36(Winter): 59-92.

Cohen, R. (1981) The new international division of labor, multinational corporations and urban hierarchy. In M. Dear and A.J. Scott (Eds.) Urbanization and Urban Planning in Capitalist Societies. New York: Methuen, pp. 287-315.

Collins, R. (1978) Positive business responses to the New Deal: the roots of the Committee for Economic Development, 1933-1942. Business History Review (Autumn).

Collins, R. (1981) The Business Response to Keynes, 1929-1964. New York: Columbia University Press.

Cox, K.R. (1973) Conflict, Power and Politics in the City. New York: McGraw Hill.

Danielson, M. (1976) The Politics of Exclusion. New York: Columbia University Press.

Davis, M. (1986) Prisoners of the American Dream: Politics and Economy in the History of the U.S. Working Class. London: Verso Books.

DeVroey, M. (1984) A regulation approach interpretation of contemporary crisis. Capital and Class 23(Summer): 45-66.

Dilger, R.J. (1982) The Sunbelt/Snowbelt Controversy: The War Over Federal Funds. New York: New York University Press.

Edwards, R. and M. Podgursky (1986) The unraveling accord: American unions in crisis. In R. Edwards, P. Garonna, and F. Todtling (Eds.) Unions in Crisis and Beyond: Perspectives from Six Countries. Dover, MA: Auburn House.

Feeley, M.M. and A.D. Sarat (1980) The Policy Dilemma: Federal Crime Policy and the Law Enforcement Administration. Minneapolis: University of Minnesota Press.

Feldman, M. and R. Florida (1989) Housing and the transformation of the postwar accumulation regime. Pittsburgh, PA: Carnegie Mellon University, School of Urban and Public Affairs Discussion Paper (October).

Ferguson, T. (1984) Normalcy to New Deal: industrial structure, party competition and American public policy in the Great Depression. International Organization 38(1): 41-94.

Ferguson, T. and J. Rogers (1986) Right Turm: The Decline of the Democrats and the Future of American Politics. New York: Hill and Wang.

Feshback, D. and L. Shipnuck (1973) Corporate regionalism in the United States. Kapitalistate 1: 14-23.

Fish, G. (1979) Housing policy in the Great Depression. In G. Fish (Ed.) The Story of Housing. New York: Macmillan.

Fleischman, A. (1977) Sunbelt boosterism: the politics of postwar growth and annexation in San Antonio. In D.C. Perry and A.J. Watkins (Eds.) The Rise of the Sunbelt Cities. Beverly Hills: Sage Publications, pp. 151-168.

Florida, R. (1986a) The origins of financial deregulation: from the CMC to Hunt Commission. In R. Florida (Ed.) Housing and the New Financial Markets. New Brunswick, NJ: Center for Urban Policy Research.

Florida, R. (1986b) The political economy of financial deregulation and the reorganization of housing finance in the US. International Journal of Urban and Regional Research 10(2): 207-231. 
Florida, R. and M. Feldman (1988) Housing in US Fordism: the class accord and postwar spatial organization. Intemational Journal of Urban and Regional Research 12: 187-210.

Foard, A. and H. Fefferman (1966) Federal urban renewal legislation. In J.Q. Wilson (Ed.) Urban Renewal. Cambridge: MIT Press.

Friedan, B.J. and M. Kaplan (1975) The Politics of Neglect: Urban Aid from Model Cities to Revenue Sharing. Cambridge: MIT Press.

Friedland, R. (1983) Power, Crisis and the City: Corporations, Unions and Urban Policy. New York: Schoken Books.

Froebel, F., J. Heinrichs, and J. Kreye (1980) The New International Division of Labor. New York: Cambridge University Press.

Gelfand, M. (1975) A Nation of Cities: The Federal Government and Urban America, 1933-1965. New York: Oxford University Press.

Glickman, N.J. (1984) Economic policy and the cities: in search of Reagan's real urban policy. Working Paper, No. 26. Austin, TX: University of Texas at Austin, Lyndon B. Johnson School of Public Affairs.

Glickman, N.J. (1985) Cities and the international division of labor. Working Paper, No. 31. Austin, TX: University of Texas at Austin, Lyndon B. Johnson School of Public Affairs.

Gordon, D., R. Edwards, and M. Reich (1982) Segmented Work, Divided Workers: The Historical Transformation of Labor in the United States. New York: Cambridge University Press.

Gourevitch, P. (1986) Politics in Hard Times. Ithaca: Cornell University Press.

Green, J.R. (1980) The World of the Worker: Labor in Twentieth Century America. New York: Hill and Wang.

Harrison, B. (1984) Regional restructuring and "good business climates": the economic transformation of New England since WW2. In W. Tabb and R. Sawers (Eds.) Snowbelt/Sunbelt: Urban Development and Regional Restructuring. New York: Oxford University Press, pp. 48-96.

Harrison, B., C. Tilly, and B. Bluestone (1986) Wage inequality takes a great U-turn. Challenge (March-April): 26-32.

Hartman, C.W. (1975) Housing and Social Policy. Englewood Cliffs, NJ: Prentice Hall.

Harvey, D.W. (1985) The Urbanization of Capital: Studies in the History and Theory of Capitalist Urbanization. Baltimore: The Johns Hopkins University Press.

Hawley, E.W. (1966) The New Deal and the Problem of Monopoly. Princeton, NJ: Princeton University Press.

Hill, R.C. (1980) Race, class and the state: the metropolitan enclave system in the United States. The Insurgent Sociologist 10(2): 45-60.

Himmelberg, R.F. (1976) The Origins of the National Recovery Administration: Business, Govemment, and the Trade Association Issue, 1921-1933. New York: Fordham University Press.

Hirsch, J. (1983) The Fordist security state and new social movements. Kapitalstate $10 / 11$.

Holcomb, H.B. and R.A. Beauregard (1981) Revitalizing Cities. Washington, D.C.: Association of American Geographers, Resource Publications in Geography.

Holloway, J. (1988) The Great Bear, post-Fordism and class struggle: a comment on Bonefeld and Jessop. Capital and Class 36(Winter): 93-104.

Horan, C. (1986) Agreeing with the bankers: New York City's depression financial crisis. In P. Zarembka (Ed.) Research in Political Economy, 8. Greenwich, CT: JAI Press.

Hymer, S. (1972) The multinational corporation and the law of uneven development. In J. Bhagwati (Ed.) Economics and World Order. New York: Free Press 
Isaac, L. and W.R. Kelly (1981) Racial insurgency, the state, and welfare expansion: local and national evidence from the postwar United States. American Journal of Sociology 86(6): 1348-1386.

Jackson, K.T. (1985) Crabgrass Frontier: The Suburbanization of the United States. New York: Oxford University Press.

Jessop, R. (1988) Regulation theory, post-Fordism and the state: more than a reply to Werner Bonefeld. Capital and Class 34(Summer): 147-168.

Judd, R. (1979) The Politics of American Cities: Private Power and Public Policy. Boston: Little Brown and Co.

Kolko, G. (1976) Main Currents in Modern American History. New York: Harper and Row.

Leuchtenberg, W.E. (1963) Franklin D. Roosevelt and the New Deal: 1932-1940. New York: Harper and Row.

Lipietz, A. (1986) New tendencies in the international division of labor: regimes of accumulation and modes of social regulation. In A.J. Scott and M. Storper (Eds.) Production, Work, Territory: The Geographical Anatomy of Industrial Capitalism. Boston: Allen and Unwin, pp. 16-40.

Lipietz, A. (1987) Mirages and Miracles: The Crises of Global Fordism. London: Verso.

Mair, A.J. (1986) The homeless and the postindustrial city. Political Geography Quarterly 5(4): 351-368.

Markowitz, N. (1973) The Rise and Fall of the People's Century: Henry A. Wallace and American Liberalism, 1941-1948. New York: Free Press.

Markusen, A., A. Saxenian, and M. Weiss (1981) Who benefits from intergovernmental transfers? In R. Burchell and D. Listokin (Eds.) Cities under Stress: The Fiscal Crisis of Urban America. New Brunswick, NJ: Center for Urban Policy Research, pp. 617-664.

Massey, D. (1984) Spatial Division of Labor: Social Structures and the Geography of Production. New York: Methuen.

Mollenkopf, J.H. (1975) The postwar politics of urban development. Politics and Society 5(3): 247-296.

Mollenkopf, J.H. (1983) The Contested City. Princeton, NJ: Princeton University Press.

Moynihan, D.P. (1969) Maximum Feasible Misunderstanding. New York: Free Press.

Muller, T. (1982) Regional impacts. In J.L. Palmer and I.V. Sawhill (Eds.) The Reagan Experiment. Washington, D.C.: The Urban Institute.

Murray, C. (1984) Losing Ground: American Social Policy, 1950-1980. New York: Basic Books.

Nathan, R.P. (1983) Retrenchment comes to Washington. Society 20(2): 45-48.

Nathan, R.P., P.M. Dearborn, C.A. Goldman, and Associates (1982) Initial effects of the Fiscal Year 1982 reductions in federal domestic spending. National Tax Joumal 35(3): 365-371.

Noel, A. (1987) Accumulation, regulation, and social change: an essay on political economy. Intemational Organization 41(2): 303-333.

O'Connor, J. (1973) The Fiscal Crisis of the State. New York: St. Martin's Press.

Orloff, A.S. and T. Skocpol (1984) Why not equal protection? Explaining the politics of public social spending in Britain, 1900-1911, and the United States, 1880s-1911. American Sociological Review 49(December): 726-750.

Page, B.I. (1983) Who Gets What from Government. Berkeley, CA: University of California Press.

Parson, D. (1984) Organized labor and the housing question: public housing, suburbanization, and urban renewal. Environment and Planning D: Society and Space 1(2): 75-86. 
Perry, D. and A.J. Watkins (Eds.) (1977) The Rise of the Sunbelt Cities. Beverly Hills, CA: Sage Publications.

Peterson, P.E. (1985) The New Urban Reality. Washington, D.C.: The Brookings Institute.

Phillips, K. (1970) The Emerging Republican Majority. Garden City, NY: Anchor Books.

Piore, M. and C. Sabel (1984) The Second Industrial Divide. New York: Basic Books.

Piven, F.F. and R.A. Cloward (1971) Regulating the Poor: The Functions of Public Welfare. New York: Pantheon.

Piven, F.F. and R.A. Cloward (1977) Poor People's Movements: Why They Succeed, How They Fail. New York: Vintage Books.

Piven, F.F. and R.A. Cloward (1982) The New Class War: Reagan's Attack on the Welfare State and Its Consequences. New York: Pantheon.

Piven, F.F. and R. Friedland (1984) Public choice and private power: a theory of the urban fiscal crisis. In A. Kirby, P. Knox, and S. Pinch (Eds.) Public Service Provision and Urban Development. New York: Croom Helm/St. Martins, pp. 390-420.

Romascu, A.U. (1983) The Politics of Recovery: Roosevelt's New Deal. New York: Oxford University Press.

Scott, A.J. (1988) Metropolis: From the Division of Labor to Urban Form. Berkeley and Los Angeles: University of California Press.

Scott, A.J. and M. Storper (Eds.) (1986) Production, Work, Territory: The Geographical Anatomy of Industrial Capitalism. Boston: Allen and Unwin.

Scott, A.J. and M. Storper (1987) High technology and regional development: a theoretical critique's reconstruction. International Social Science Review 112: 215-232.

Scott, B.R. (1985) US competitiveness: concepts, performance, and implications. In B.R. Scott and G.C. Lodge (Eds.) U.S. Competitiveness in the World Economy. Boston: Harvard Business School Press.

Semer, M. (1976) Evolution of federal legislative policy in housing: housing credit. In U.S. Department of Housing and Urban Development, Housing in the Seventies. Washington, D.C.: US Government Printing Office.

Shefter, M. (1987) Political Crisis/Fiscal Crisis: The Collapse and Revival of New York City. New York: Basic Books.

Smith, N. (1989) Lower East Side as Wild Wild West: New York City as Frontier. Baltimore: Paper presented at the Annual Meetings of the Association of American Geographers, March.

Stanback, T.M. and Noyelle, T.J. (1982) Cities in Transition. Totowa, NJ: Allenheld, Osmun.

Starr, R. (1975) Housing and the Money Market. New York: Basic Books.

Sternlieb, G. and J.W. Hughes (Eds.) (1975) Post-Industrial America: Metropolitan Decline and Inter-Regional Job Shifts. New Brunswick, NJ: Center for Urban Policy Research.

Stone, M. (1973) Federal housing policy: a politico-economic analysis. In H. Pynoos et al. (Eds.) Housing Urban America. Chicago: Aldine.

Storper, M. and A.J. Scott (1989) The geographical foundations and social regulation of flexible production complexes. In J. Wolch and M. Dear (Eds.) The Power of Geography: How Territory Shapes Social Life. Boston: Unwin Hyman, pp. 21-40.

Tabb, W. (1982) The Long Default. New York: Monthly Review Press.

Teaford, J.C. (1986) The Twentieth Century American City: Problem, Promise, and Reality. Baltimore: The Johns Hopkins University Press. 
U.S. Advisory Commission on Intergovernmental Relations (1980) The Federal Role in the Federal System: The Dynamics of Growth - Public Assistance: The Growth of a Federal Function. Washington, D.C.: US Government Printing Office.

U.S. Bureau of the Census (1975) Historical Statistics of the United States: Colonial Times to 1970. Washington, D.C.: US Government Printing Office, Series D-86.

U.S. Office of Management and Budget (1982) Budget of the United States Govemment, Fiscal Year 1982. Washington, D.C.: US Government Printing Office.

U.S. Office of Management and Budget (1986) Budget of the United States Government, Fiscal Year 1987. Washington, D.C.: US Government Printing Office.

Van der Pijl, K. (1984) The Making of an Atlantic Ruling Class. London: Verso Books.

Walker, R. (1977) The suburban solution: urban geography and urban reform in capitalist development. Unpublished PhD Dissertation, The Johns Hopkins University, Department of Geography.

Walker, R. (1981) A theory of suburbanization: capital and the construction of urban space in the United States. In M.J. Dear and A.J. Scott (Eds.) Urbanization and Urban Planning in Capitalist Societies. New York: Methuen.

Weiss, M.A. (1980) The origins and legacy of urban renewal. In P. Clavel, J. Forester, and W.W. Goldsmith (Eds.) Urban and Regional Planning in an Age of Austerity. New York: Pergamon Press, pp. 53-80.

Wilson, W.J. (1980) The Declining Significance of Race: Blacks and Changing American Institutions. Chicago: University of Chicago Press.

Wilson, W.J. (1985) The urban underclass in an advanced industrial society. In P.E. Peterson (Ed.) The New Urban Reality. Washington, D.C.: The Brookings Institute, pp. 129-160.

Wolch, J. and M. Dear (Eds.) (1989) The Power of Geography: How Territory Shapes Social Life. Boston: Unwin Hyman.

Wolfe, A. (1981) America's Impasse: The Rise and Fall of the Politics of Growth. New York: Pantheon. 